\title{
Nitrogen (N) Mineral Nutrition and Imaging Sensors for Determining N Status and Requirements of Maize
}

\author{
Abdelaziz Rhezali ${ }^{1, *}$ and Rachid Lahlali ${ }^{2,3}$ \\ 1 Faculty Crop, Soil and Environmental Science, University of Arkansas, Fayetteville, AR 72701, USA \\ 2 Canadian Light Source Inc., University of Saskatchewan, Saskatoon, SK S7N 2V3, Canada; \\ lahlali.r@gmail.com \\ 3 Currently Department of Crop Protection, Phytopathology Unit, Ecole Nationale d'Agriculture de Meknès, \\ BP/S 40, Meknès 50001, Morocco \\ * Correspondence: rhezalienam@gmail.com; Tel.: +1-212-663-481-171
}

Received: 18 June 2017; Accepted: 9 November 2017; Published: 14 November 2017

\begin{abstract}
Nitrogen $(\mathrm{N})$ is one of the most limiting factors for maize (Zea mays L.) production worldwide. Over-fertilization of $\mathrm{N}$ may decrease yields and increase $\mathrm{NO}_{3}{ }^{-}$contamination of water. However, low $\mathrm{N}$ fertilization will decrease yields. The objective is to optimize the use of $\mathrm{N}$ fertilizers, to excel in yields and preserve the environment. The knowledge of factors affecting the mobility of $\mathrm{N}$ in the soil is crucial to determine ways to manage $\mathrm{N}$ in the field. Researchers developed several methods to use $\mathrm{N}$ efficiently relying on agronomic practices, the use of sensors and the analysis of digital images. These imaging sensors determine $\mathrm{N}$ requirements in plants based on changes in Leaf chlorophyll and polyphenolics contents, the Normalized Difference Vegetation Index (NDVI), and the Dark Green Color index (DGCI). Each method revealed limitations and the scope of future research is to draw N recommendations from the Dark Green Color Index (DGCI) technology. Results showed that more effort is needed to develop tools to benefit from DGCI.
\end{abstract}

Keywords: nitrogen; maize; maximum yield; sensors; NDVI; DGCI

\section{Introduction}

Maize (Zea mays L.) is an important crop in the U.S. with an estimated production area of 39.4 million hectares in 2013 and an average yield of $9.34 \mathrm{Mg} \cdot \mathrm{ha}^{-1}$ during the last 10 growing seasons [1]. To achieve high yields, fertilization is a critical factor, and nitrogen $(\mathrm{N})$ is considered essential in plant mineral nutrition [2]. Currently, more than half of the world's population depends on food production made possible by the use of $\mathrm{N}$ fertilizers, especially in cereal crops [3].

Nitrogen plays an important and vital role in cellular metabolism [4]. Nitrate is mobile and stored in vacuoles. Nitrate reductase converts nitrate into nitrite. This complicated biochemical reaction occurs in the non-organelle portion of the cytoplasm. The primary functions of $\mathrm{N}$ are to provide amino groups in amino acids as well as to contribute in the biochemistry of many nonprotein compounds such as co-enzymes, photosynthetic pigments, secondary metabolites, and polyamines [5]. In fact, proteins contain $85 \%$ of the total $\mathrm{N}$ in the plant [6].

Studies have established a strong correlation between $\mathrm{N}$ content and photosynthetic activity in plant cells $[5,7]$. Nitrogen fertilization is a crucial factor in improving crops yields. However, over-fertilization of $\mathrm{N}$ does not improve crop yield and can reduce crop profitability by wasting fertilizer and leading to pollution of ground and surface waters [8,9]. Raun and Johnson [10] and Ladha et al. [3] reported that around $67 \%$ of $\mathrm{N}$ fertilizer used in cereal production worldwide was lost due to denitrification, surface runoff, volatilization, and leaching. For example, the global annual amount of nitrous oxide (NO) emissions from fertilized crops due to $\mathrm{N}$ denitrification and ammonia volatilization was about $3300 \mathrm{Mg}$, leading to a rise of greenhouse gases in the atmosphere [11,12]. 
Undoubtedly, under-estimating $\mathrm{N}$ fertilization needs may lead to low crop yields, and $\mathrm{N}$ uptake is very much affected by $\mathrm{N}$ fertilizer rates [2,13]. Nitrogen deficiency impacts negatively the growth of plants organs and leads to the loss of the green color [14]. Nitrogen fertilization influences total $\mathrm{N}$ uptake as well as total crop biomass production. For example, $\mathrm{N}$ uptake in maize increased from approximately $40 \mathrm{~kg} \mathrm{~N} \cdot \mathrm{ha}^{-1}$ to $95 \mathrm{~kg} \cdot \mathrm{N} \cdot \mathrm{ha}^{-1}$, and 3 grain yield in maize increased from 2.3 to $4.9 \mathrm{Mg} \cdot \mathrm{ha}^{-1}$ when $120 \mathrm{~kg} \cdot \mathrm{N} \cdot \mathrm{ha}^{-1}$ was applied compared to the no-N control [15-17]. Shapiro and Wortman [2] determined that yield of irrigated maize increased with increasing $\mathrm{N}$ applications, until maize production plateaued, and then decreased.

The challenge today is to improve the efficiency of fertilizer use to avoid the adverse environmental impacts of $\mathrm{N}$ fertilizer. Several methods are used to improve $\mathrm{N}$ use efficiency (NUE), which is the ratio of grain yield to $\mathrm{N}$ supply ( $\mathrm{kg}$ grain $\mathrm{kg} \cdot \mathrm{N}^{-1}$ ) [18]. Some of the techniques rely on agronomic practices, such as choosing the appropriate $\mathrm{N}$ fertilizer source, correct timing of $\mathrm{N}$ application, placement of $\mathrm{N}$ application, and the rate of $\mathrm{N}$ fertilizer [17]. Some scientists have developed different strategies to reduce $\mathrm{NO}_{3}{ }^{-}$leaching and recommended $\mathrm{N}$ fertilization rates based on potential maize yield, soil $\mathrm{C}$ and $\mathrm{N}$ mineralization, NUE's and $\mathrm{N}$ response trials $[19,20]$.

A different approach to improve NUE is the use of remote sensing tools to assess plant $\mathrm{N}$ and to formulate $\mathrm{N}$ recommendations based on leaf chlorophyll concentration or leaf greenness. For example, Samborski et al. [21] summarized a general review of reflectance sensors like the Chlorophyll Meter, the Green Seeker, the Crop Circle, the Fieldscan, and the Dualex, and reported the advantages and limitations of each sensor using wavelengths in assessing plant $\mathrm{N}$ status. Others like Pagola et al. [22] and Rorie et al. [23] determined that color image analysis from a digital camera was an effective tool to estimate plant $\mathrm{N}$ status. Purcell et al. [24] developed algorithms for $\mathrm{N}$ fertilization based on color image analysis, and this approach has been utilized in an app for iDevices called Greenindex+ that is marketed by Spectrum Technologies [25]. The focus of this review is to describe the maize $\mathrm{N}$ mineral nutrition and give an overview on sensor tools for assessing maize plant $\mathrm{N}$ status and recommending appropriate $\mathrm{N}$ quantities for maize.

\section{Maize Nitrogen Mineral Nutrition}

\subsection{Nitrogen Metabolism in the Plant}

Nitrogen stimulates root growth, and the uptake of other nutrients $[5,26,27]$. Generally, $85 \%$ of the total $\mathrm{N}$ in plants is associated with proteins [28]. The plant as $\mathrm{NO}_{3}{ }^{-}$and $\mathrm{NH}_{4}{ }^{+}$takes up nitrogen, which are considered mineral forms and are referred to as residual soil N. Once $\mathrm{NO}_{3}{ }^{-}$is absorbed, it is either stored in vacuoles or reduced to $\mathrm{NH}_{4}{ }^{+}$via the intervention of two enzymes: $\mathrm{NO}_{3}{ }^{-}$reductase, which converts $\mathrm{NO}_{3}{ }^{-}$to $\mathrm{NO}_{2}{ }^{-}$, and $\mathrm{NO}_{2}{ }^{-}$reductase, which reduces $\mathrm{NO}_{2}{ }^{-}$to $\mathrm{NH}_{4}{ }^{+}$[29]. Ammonium is assimilated through glutamine synthethase and metabolized into amino acids and amides [30,31].

The concentration of $\mathrm{N}$ in the plant has a strong relationship with its growth, and $\mathrm{N}$ deficiencies may alter or inhibit plant growth. The plant is unable to achieve its maximum growth if the concentration of any nutrient in tissue is below the critical concentration. Nitrogen excess leads to a phenomenon called luxury consumption. The excess of $\mathrm{N}$ does not contribute to an increase of yield because the plant doses not metabolized into functional or structural compounds. The sufficiency

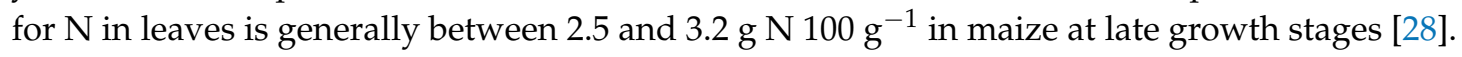

Nitrogen deficiency decreases leaf area formation, and as a consequence reduces the amount of solar radiation intercepted [32,33]. Nitrogen requirements are moderate at early maize growth stages but increases greatly after the V8 stage. By tasseling stage (VT), maize has accumulated approximately $76 \%$ of the $\mathrm{N}$ found in mature plants (Table 1, Leikman et al. [33]). Although young maize plants need relatively small amounts of $\mathrm{N}$, deficiency at early growth stages should be avoided, since yield components in maize are set between V6 and V8. 
Table 1. Accumulation of $\mathrm{N}$ in maize throughout the season [33].

\begin{tabular}{cccc}
\hline Growth Stage & Days after Emergence & \% of N Uptake of N Amount Applied & \% of Final N Accumulated \\
\hline 4-leaf & 32 & 0.81 & $<1$ \\
8-leaf & 44 & 2.16 & 3 \\
12-Leaf & 59 & 5.6 & 9 \\
Tassel & 72 & 15.33 & 23.9 \\
Silk & 84 & 14.18 & 38.7 \\
Blister & 108 & 15.4 & 54.1 \\
Early dent & 139 & 23.17 & 77.3 \\
Maturity & 144 & 23.31 & 100 \\
\hline
\end{tabular}

\subsection{Nitrogen in Soils}

The total $\mathrm{N}$ concentration of surface mineral soils generally ranges from 0.02 to $0.5 \%$, which is around $3.3 \mathrm{Mg} \cdot \mathrm{ha}^{-1}$. Most of the $\mathrm{N}$, however, remains in organic forms with only around 2 to $3 \%$ of the organic-N mineralized throughout the growing season. The primary $\mathrm{N}$ cycle reactions or transformations identified in the soil are [26]:

- Biological $\mathrm{N}$ fixation: is a process by which $\mathrm{N}_{2}$ in the atmosphere is converted into $\mathrm{NH}_{4}{ }^{+}$.

- Mineralization: is the conversion of organic- $\mathrm{N}$ to $\mathrm{NH}_{4}{ }^{+}$.

- Nitrification: The process of the transformation of $\mathrm{NH}_{4}{ }^{+}$into $\mathrm{NO}_{3}{ }^{-}$.

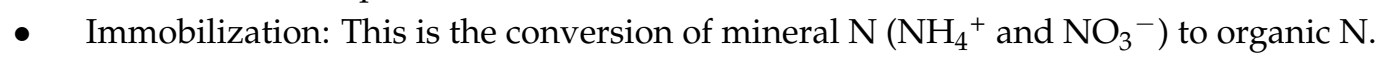

- Volatilization: This is the transformation of $\mathrm{CO}\left(\mathrm{NH}_{2}\right)_{2}$ to $\mathrm{NH}_{3}$ gas.

- Denitrification: This is the reduction of $\mathrm{NO}_{3}{ }^{-}$to $\mathrm{NO}$ and $\mathrm{N}_{2}$.

Mineralization and immobilization rate depends on the chemical composition of the residue, specifically the $\mathrm{C} / \mathrm{N}$ ratio of the residue $[34,35]$. A C/N ratio greater than 20 leads to the immobilization of the residual $\mathrm{N}$ pool while a ratio less than 15 leads to the mineralization of the organic $\mathrm{N}$ pool. For example, wheat (Triticum aestivum) straws are slow to mineralize ( $\mathrm{C} / \mathrm{N}=80$ to 90 ) in comparison to green leaves of oilseed rape (Brassica napus) or maize (Zea mays) ( $\mathrm{C} / \mathrm{N}=10$ to 15), which mineralize rapidly.

Ammonia is subject to loss due to volatilization especially when urea is applied to moist soils. In addition, $\mathrm{NO}_{3}{ }^{-}$is susceptible to denitrification and leaching that occurs in saturated soil conditions. The choice of fertilizer, application timing, and fertilizer placement method are important considerations to minimize $\mathrm{N}$ losses from the soil. For example, $\mathrm{N}$ losses are significant when fertilizers are applied at once without any partitioning and/or directly to the soil without any incorporation [26].

\subsection{Nitrogen Management in Maize}

Nitrogen management for maize production varies across the world due to differences in soil characteristics, weather conditions, hybrid availability, and yield expectations. In less industrialized regions, farmers use farmyard manure applied at a rate of about $15 \mathrm{Mg} \cdot \mathrm{ha}^{-1}$ or apply urea as a top dressing at an average application rate between 5 and $25 \mathrm{~kg} \mathrm{~N} \cdot \mathrm{ha}^{-1}$ [36]. Sometimes, farmyard manure is substituted by compost $\left(8 \mathrm{Mg} \cdot \mathrm{ha}^{-1}\right)$ where available and others broadcast urea or ammonium sulfate at around 80 to $100 \mathrm{~kg} \mathrm{~N} \cdot \mathrm{ha}^{-1}$ at the time of planting [36]. In Arkansas, researchers [37] determined that in general, $1 \mathrm{~kg} \cdot \mathrm{N} \mathrm{ha}{ }^{-1}$ returned $50 \mathrm{~kg}$ grain $\mathrm{ha}^{-1}$. They gave detailed requirements of $\mathrm{N}$ fertilizer needs based on soil texture and yield goal (Tables 2 and 3).

Others [38] determined that $202 \mathrm{~kg} \cdot \mathrm{N} \mathrm{ha}^{-1}$ was sufficient to achieve the optimal yield in silty clay loam and silt loam soils, but beyond this $\mathrm{N}$ rate, maize grain yield leveled off. Shapiro and Wortman [2] found during a two-year experiment that maize yield response to $\mathrm{N}$ fertilization in silty clay soils fit a quadratic model, and that the optimum $\mathrm{N}$ rate that gave the maximum yield was $198 \mathrm{~kg} \cdot \mathrm{N} \cdot \mathrm{ha}{ }^{-1}$ and $145 \mathrm{~N} \cdot \mathrm{kg} \cdot \mathrm{ha}^{-1}$ for the first and the second years, respectively.

In situations of high residual $\mathrm{N}$ (between 46 and $92 \mathrm{~kg} \cdot \mathrm{NO}_{3}{ }^{-} \cdot \mathrm{ha}^{-1}$ in $0-30 \mathrm{~cm}$ depth), maize does not respond to $\mathrm{N}$ fertilization [39]. The same author identified maize as a crop, which quickly reduces 
residual $\mathrm{N}$ over years. Residual $\mathrm{N}$ in a soil profile of $30 \mathrm{~cm}$ may drop around $87 \%$ after four years of consecutive maize.

On the other hand, N application greatly affects NUE in maize [21]. Abbasi et al. [17] determined that providing one half of the total $\mathrm{N}$ at sowing and the other half at V6 decreased $\mathrm{N}$ losses by denitrification, immobilization and leaching. In comparison to a single pre-plant, $\mathrm{N}$ application, N plant uptake and harvest index increased by 16 and 39\%, respectively. This study confirmed research which [40] determined that a split application (one-third at planting and two-thirds as sidedress) was enough to maximize yield and increase NUE. Slow or controlled-release fertilizer and placement of $\mathrm{N}$ more precisely in the soil can also improve NUE [21].

Table 2. Fertilizer recommendations $\left(\mathrm{kg} \cdot \mathrm{ha}^{-1}\right)$ for maize grown in Sandy Loams or Silt Loams, based on yield goal [37].

\begin{tabular}{|c|c|c|}
\hline Yield Goal kg·ha ${ }^{-1}$ & Recommended N, kg.ha ${ }^{-1}$ & $\mathrm{~kg}$ Yield $\cdot \mathrm{kg}^{-1} \mathrm{~N}$ \\
\hline Up to 7875 & 134 & 69 \\
\hline 9450 & 168 & 56 \\
\hline 11,025 & 202 & 55 \\
\hline 12,600 & 235 & 54 \\
\hline 14,175 & 268 & 53 \\
\hline
\end{tabular}

Table 3. Fertilizer recommendations $\left(\mathrm{kg} \cdot \mathrm{ha}^{-1}\right)$ and nitrogen use efficiency (NUE) for maize grown in silty clays, silty clay loams, and clays, based on yield goal [37].

\begin{tabular}{ccc}
\hline${\text { Yield Goal } \mathbf{~ g} \cdot \mathbf{h a}^{\mathbf{- 1}}}$ & Recommended $\mathbf{N ~} \mathbf{~ g} \cdot \mathbf{h a}^{\mathbf{- 1}}$ & $\mathbf{N U E} \mathbf{~ k g} \cdot \mathbf{k g}^{\mathbf{- 1}} \mathbf{N}$ \\
\hline Up to 6300 & 140 & 45 \\
7560 & 196 & 39 \\
8820 & 252 & 35 \\
10,080 & 336 & 30 \\
\hline
\end{tabular}

Pre-sidedress nitrate testing (PSNT) is another way to predict $\mathrm{N}$ requirements and potentially minimize $\mathrm{NO}_{3}{ }^{-}$losses. This test measures soil $\mathrm{NO}_{3}{ }^{-}$levels in the top $30 \mathrm{~cm}$ when maize plants are $30-\mathrm{cm}$ tall [41]. Pre-sidedress nitrate testing is a useful tool since it can predict in-season, sidedress $\mathrm{N}$ requirement early in the growing season, especially on manured soils or soils that have received large applications of fertilizer [21,42]. Pre-sidedress nitrate testing may reduce the amount of $\mathrm{NO}_{3}{ }^{-}$ leached by predicting small $\mathrm{N}$ quantities required, hence, contributing to a reduction of ground water pollution [43]. However, PSNT has some constraints such as high labor requirements as well as short timing between soil testing and the time that fertilizer should be applied, which has slowed down the adoption of this technique by farmers [44].

\section{Imaging Sensors to Determine N Requirements in-Season}

Remote sensing techniques provide a platform for which plant stress and growth response can be evaluated. Sensors have been developed to measure the reflectance of incident light at various wavelengths and have been related to plant growth and vegetative cover. The use of vegetative indices has allowed users to relate differences in reflectance to changes in canopy characteristics [45]. There are numerous indices, all derived from ratios based on the reflectance of incident light at specific wavelengths. Spectral information has been used to evaluate micronutrient stress, detection of insect infestation, and disease infection of plants [46]

In recent years, several different sensors have been used to assess plant $\mathrm{N}$ status. The chlorophyll, or Special Products Analysis Division (SPAD) meter, estimates chlorophyll concentration in the leaf, which is correlated with leaf $\mathrm{N}$ concentration [47]. The SPAD meter calculates the red light absorbed by the leaf. The more absorbed red light, the greater the chlorophyll concentration in the 
leaf. The relationship between the SPAD meter values and leaf chlorophyll concentration is curvilinear following either exponential or polynomial functions [48].

\subsection{Leaf Chlorophyll and Polyphenolics Measurement Method}

The quality and productivity of crop are directly related to the green pigment visible in the leaves, which is due to the presence of chlorophyll. Leaf chlorophyll is mostly used as an index to diagnose diseases and getting the nutrient and nitrogen status in the plants [49]. Hence, the chlorophyll meter is a promising tool in leaf $\mathrm{N}$ assessment [47], and identifies $\mathrm{N}$ deficiencies in plants [50,51]. Varvel et al. [52] determined that to improve chlorophyll meter efficiency in predicting sidedress $\mathrm{N}$ needs (based on sufficiency index), maize $\mathrm{N}$ deficiency must be avoided during early growth stages. The best time for SPAD measurements for maize is V6, at which time chlorophyll meter readings are well correlated with leaf $\mathrm{N}$ concentration [51]. Unfortunately, the chlorophyll meter presents some limitations as it is expensive (\$2500), has only a small sampling area of $6 \mathrm{~mm}^{2}$, and does not have the ability to detect small deficiencies ([51,53].

In addition to the leaf chlorophyll ( $\mathrm{Chl}$ ) content, researchers proposed the use of the leaf content of polyphenolics (Phen) as a potential indicator of crop N status. Because of their absorption features in the visible and in the UV part of the spectrum, both Chl and Phen can be measured by rapid and non-destructive optical methods [54]. The Dualex (Dynamax Inc., Houston, TX, USA) sensor is also used to assess $\mathrm{N}$ status in the plant by calculating the amount of polyphenolics in the leaf, which are associated with leaf $\mathrm{N}$ concentration. Sensors using near infrared radiance were able to predict optimum $\mathrm{N}$ rate for maize at tasseling but not at early growth stage in maize [55]. In contrast, Scharf and Lory [56] determined a strong linear relationship between economic optimum $\mathrm{N}$ rate for maize and near infrared radiance at $\mathrm{V} 7$, when soil pixels were removed from the pictures.

\subsection{The Normalized Difference Vegetation Index (NDVI)}

NDVI has been used to evaluate plant nitrogen status, chlorophyll content, green leaf biomass and grain yield [57-59]. The normalized difference vegetative index (NDVI) has gained wide acceptance based on its ease of use, only requiring two wavelengths, and the plant characteristics that have also been correlated. The Normalized Difference Vegetation Index (NDVI) is also a measurement that has been used extensively to assess $\mathrm{N}$ status in maize and other crops [60,61]. For instance, Crop Circle (Holland Scientific, Lincoln NE) has the ability to predict $\mathrm{N}$ rates to correct in-season deficiency in corn using NDVI $[62,63]$. An NDVI measurement occurs at two wavelengths; the first wavelength (from 0.4 to $0.7 \mu \mathrm{m}$ ) is associated with chlorophyll adsorption and the second wavelength is unabsorbed (from 0.7 to $1.1 \mu \mathrm{m}$ ). An NDVI number is the result of a comparison between the two measurements [56]. There is a strong correlation between NDVI values and N concentration in the canopy [64]. In addition, Mullen et al. [61] determined a high correlation between NDVI and grain yield of wheat. Commercial products using NDVI technology include the Green Seeker (Trimble, Auburn, AL, USA), the Field scan (Process Sensor Corp, Milford, MA, USA) and the Dualex (Dynamax Inc., Houston, TX, USA) [62,63]. Costs of the Crop circle or Dualex are about $\$ 2000$ or more, thus hampering their use by farmers. On the other hand, NDVI can be used in other fields. Multi spectral analysis is a way to manage urban areas and perform municipal planning. In case of a disaster, NDVI is a great tool to facilitate intervention for humanitarian help [65].

Two types of NDVI instruments exist: those with passive and those with active sensors. Passive-sensor instruments rely on natural energy that is reflected or emitted from the observed scene to calculate NDVI, and external sunlight is the most common external source of radiation used by passive NDVI sensors. Passive NDVI sensors are not hyper-spectral, although most hyper-spectral sensors are passive. On the other hand, NDVI instruments with active sensors are equipped with light-emitting components that provide energy to illuminate the object they observe. Active sensors can be used independently of solar radiation but can only deal with specific wavelengths according to the type of light sensors [45]. 
NDVI is well correlated with plant $\mathrm{N}$ uptake, but it is prone to saturation with high $\mathrm{N}$ concentration or with green leaf area index LAI exceeding 2.5 to 3 [66]. In addition, canopy cover affects directly the reflectance for $\mathrm{N}$ concentration. NDVI assessment for maize leaf $\mathrm{N}$ concentration is biased when canopy cover is less than 100\% [67]. A comparison between an active sensor and many passive sensors reported that the active NDVI sensor was less effective than the passive NDVI sensor in estimating green cover of wheat $\left(r^{2}=0.9\right.$ for the passive sensors $v s r^{2}=0.8$ for the active sensor) [68]. In maize, for a maximum of effectiveness of sidedress $\mathrm{N}$ application, measurements using an active sensor should be made from V8 to V12 corn growth stage [69].

\subsection{The Dark Green Color Index (DGCI)}

Another technology that may give an appropriate way to assess plant $\mathrm{N}$ status is the intensity of green color from digital images of leaves. The camera records the image, and special software analyzes the image by measuring the greenness of the leaf based on red, green, blue (RGB) colors of the picture. The RGB values are converted into hue, saturation and brightness values using a method described by Karcher and Richardson [70] to calculate the Dark Green Color index (DGCI):

$$
\mathrm{DGCI}=[(\text { Hue }-60) / 60+(1-\text { Saturation })+(1-\text { Brightness })] / 3 .
$$

The resulting DGCI value is on a scale from 0 (very yellow) to 1 (dark green). Karcher and Richardson [70] and Rorie et al. [23] found DGCI an accurate tool to estimate N leaf concentration in turfgrass and maize, respectively. For example, Rorie et al. [23] quantified maize leaf greenness with a digital camera and image analysis software (Sigma Scan Pro 5, SPSS, 1998, San Jose, CA, USA) in terms of DGCI by modifying the digital-imaging method of Karcher and Richardson [70]. Rorie et al. [23] photographed the ear leaf of maize at tasseling against a pink board (to provide contrast in subsequent image processing) that had two internal color standards disks with known DGCI values (0.5722 for the green disk and 0.073 for the yellow disk). Color standards were included in each image to allow corrections of variations due to different conditions of light. This analysis established close relationships between leaf DGCI, leaf N concentration, SPAD and yield.

In subsequent research, Purcell et al. [24] developed a calibration curve for the amount of $\mathrm{N}$ to be applied at midseason to recover $90 \%$ or $95 \%$ of maximum yield based upon DGCI values made using a digital camera, measured at V6-V10 from the uppermost collared leaf. The DGCI was determined efficient in calculating the amount needed to apply for maize in silt loam soils. The DGCI prediction could save 60 units of $\mathrm{N}$ per hectare without impacting yield [71].

Based upon algorithms from Purcell et al. [24], Spectrum Technology (Aurora, IL, USA) [25] developed an iPhone app called Greenindex+ that assessed leaf $\mathrm{N}$ maize status and therefore predict the requirements of maize in nitrogen. The app was supposed to determine directly the DGCI values and leaf $\mathrm{N}$ concentration. However, research considers possible reasons for discrepancies between the method of Purcell et al. [24] and the Greenindex+ app [71]

\section{Current State and Future Prospects}

Sensors like the chlorophyll meter and the Dualex are promising tools to predict $\mathrm{N}$ requirements for maize. However, their costs, which are high (more than \$2000), slowed down their adoption by farmers. The dark green color index (DGCI), which is not an expensive technology, is a tool that could potentially change how farmers determine the quantity of $\mathrm{N}$ fertilizer to apply to maize.

Future research might work further on this technology to overcome discrepancies between the app and the camera. In another research, the assessment of greenness using DGCI was effective in determining $\mathrm{N}$ concentration in soybean [72]. The DGCI would be a great technology to use in drones. The ultimate goal for researchers is to develop solutions in order to use this technology efficiently. Indeed, the classical method calculating DGCI after processing pictures in a special software as cited above requires proficiency in manipulating Excel files and image analysis software. At that point, 
DGCI requires a high education level. Applications installed in drones could be good solutions for farmers so they can adopt and benefit from DGCI technology.

Acknowledgments: We are grateful to the Faculty Crop, Soil and Environmental Science, University of Arkansas, which provided financial support for this master thesis and to the advisor Purcell for his precious guidance.

Author Contributions: Abdelaziz Rhezali and Rachid Lahlali wrote the paper. All authors reviewed, commented and approved the manuscript for submission.

Conflicts of Interest: The authors declare no conflict of interest. The founding sponsors had no role in the design of the study; in the collection, analyses, or interpretation of data; in the writing of the manuscript, and in the decision to publish the results.

\section{References}

1. USDA. International Data Base 2013. National Agricultural Statistics Services: Washington, DC, USA. Available online: http:/ / www.nass.usda.gov/Statistics_by_Subject/index.php?sector=CROPS (accessed on 10 November 2017).

2. Shapiro, C.A.; Wortmann, C.S. Corn response to nitrogen rate, row spacing and plant density in Eastern Nebraska. Agron. J. 2006, 98, 529-535. [CrossRef]

3. Ladha, K.J.; Pathak, H.; Krupnik, T.J.; Six, J.; van Kessel, C. Efficiency of Fertilizer nitrogen in cereal production: Retrospects and prospects. Adv. Agron. 2005, 87, 85-156.

4. McKeem, H.S. Nitrogen Metabolism in Plants; Oxford University Press: London, UK, 1962; pp. 1-18.

5. Maathuis, F.J.M. Physiological functions of mineral macronutrients. Curr. Opin. Inplant Biol. 2009, 2, 250-258. [CrossRef] [PubMed]

6. Pearsall, W.H. The distribution of the insoluble nitrogen in Beta leaves of different ages. J. Exp. Biol. 1931, 8, 279-285.

7. Wullschleger, S.D. Biochemical limitations to carbon assimilation in C3 plants-A retrospective analysis of the A/Ci curves from 109 species. J. Exp. Bot. 1993, 44, 907-920. [CrossRef]

8. Hallberg, G.R. Nitrogen Management and Ground Water Protection; Follett, R.F., Ed.; Elsevier: Amsterdam, The Netherlands, 1989; p. 74.

9. Cox, W.J.; Kalonge, S.; Cherney, D.J.R.; Reid, W.S. Growth, yield, and quality of forage corn under different nitrogen management practices. Agron. J. 1993, 85, 341-347. [CrossRef]

10. Raun, R.W.; Johnson, G.V. Improving nitrogen use efficiency for cereal production. Agron. J. 1999, 91, 357-363. [CrossRef]

11. Stehfest, E.; Bouwman, $\mathrm{L} . \mathrm{N}_{2} \mathrm{O}$ and $\mathrm{NO}$ emission from agricultural fields and soils under natural vegetation: Summarizing available measurement data and modeling of global annual emissions. Nutr. Cycl. Agroecosyst. 2006, 74, 207-228. [CrossRef]

12. Savci, S. Investigation of effect of chemical fertilizers on environment. APCB Procedia 2012, 1, 287-292. [CrossRef]

13. Halvorson, D.A.; Mosier, A.R.; Reule, C.A.; Bausch, W.C. Nitrogen and tillage effects on irrigated continuous corn yields. Agron. J. 2006, 98, 63-71. [CrossRef]

14. Tucker, T.C. Diagnosis of nitrogen deficiency in plants. In Nitrogen in Crop Production; Hauck, R.D., Ed.; American Society of Agronomy: Madison, WI, USA, 1984; pp. 249-262.

15. Abbasi, M.K.; Khaliq, A.; Shafiq, M.; Kazmi, M.; Ali, I. Comparative effectiveness of urea N, poultry manure and their combination in changing soil properties and maize productivity under rainfed conditions in northeast Pakistan. Exp. Agric. 2010, 46, 211. [CrossRef]

16. Abbasi, M.K.; Tahir, M.M.; Sadiq, A.; Iqbal, M.; Zafar, M. Yield and nitrogen use efficiency of rainfed maize response to splitting and nitrogen rates in Kashmir, Pakistan. Agron. J. 2012, 104, 448. [CrossRef]

17. Abbasi, M.K.; Tahir, M.M.; Rahim, N. Effect of $\mathrm{N}$ fertilizer source and timing on yield and $\mathrm{N}$ use efficiency of rainfed maize (Zea mays L.) in Kashmir-Pakistan. Geoderma 2013, 195, 87-93. [CrossRef]

18. López-Bellido, R.; López-Bellido, L. Efficiency of nitrogen in wheat under Mediterranean conditions: Effect of tillage, crop rotation and N fertilization. Field Crop. Res. 2001, 71, 31-46. [CrossRef]

19. Schepers, J.S.; Varvel, G.E.; Watts, D.G. Nitrogen and water management strategies to reduce nitrate leaching under irrigated maize. J. Contam. Hydrol. 1995, 20, 227-239. [CrossRef] 
20. Setiyono, T.D.; Yang, H.; Walters, D.T.; Dobermann, A.; Ferguson, R.B.; Roberts, D.F.; Lyon, D.J.; Clay, D.E.; Cassaman, K.G. Maize-N: A decision tool for nitrogen management in maize. Agron. J. 2011, 103, 1276-1283. [CrossRef]

21. Samborski, S.M.; Tremblay, N.; Fallon, E. Strategies to make use of plant sensors based diagnostic information for nitrogen recommendations. Agron. J. 2009, 101, 800-816. [CrossRef]

22. Pagola, M.; Ortiz, R.; Ignacio, I.; Bustince, H.; Barrenechea, E.; Tejo, P.A.; Lamsfus, C.; Lasa, B. New method to assess barley nitrogen nutrition status based on image color analysis comparison with SPAD-502. Comput. Electron. Agric. 2009, 65, 213-218. [CrossRef]

23. Rorie, R.L.; Purcell, L.C.; Mozaffari, M.; Karcher, D.E.; King, A.C.; Marsh, M.C.; Longer, D.E. Association of "greenness" in corn with yield and leaf nitrogen concentration. Agron. J. 2011, 103, 529-535. [CrossRef]

24. Purcell, L.C.; Siddons, U.G.; Karcher, D.E.; Rorie, R.L. System and Method of in Season Nitrogen Measurement and Fertilization of Non-Leguminous Crops from Digital Image Analysis. U.S. Patent 9,117,140 B2, 25 August 2015.

25. Chlorophyll Meters. Available online: https://www.specmeters.com/nutrient-management/chlorophyllmeters / (accessed on 10 November 2017).

26. Brady, N.C. Nitrogen and sulfur economy in soils. In Nature and Properties of Soil; Macmillan Publishing Company: Basingstoke, UK, 1990; p. 621.

27. Oikeha, S.O.; Klinga, J.G.; Horstb, W.J.; Chudec, V.O.; Carskya, R.J. Growth and distribution of maize roots under nitrogen fertilization in plinthite soil. Field Crops Res. 1999, 61, 1-13. [CrossRef]

28. Barker, V.A.; Bryson, G.M. Nitrogen. In Hand Book of Plant Nutrition; Taylor and Francis: Abingdon, UK, 2007; p. 661.

29. Evans, J.H.; Nason, A. Pyridine nucleotide nitrate reduction from higher plants. Plant Physiol. 1953, 28, 233-254. [CrossRef] [PubMed]

30. Baron, A.C.; Tobin, T.H.; Wallsgrove, R.M.; Tobin, A.K. A metabolic control analysis of the glutamine synthetase/glutamate synthase cycle in isolated barely in isolated barely (Hordeumvulgare L.) chloroplasts. Plant Physiol. 1994, 105, 415-424. [CrossRef] [PubMed]

31. Lea, J.P.; Ireland, R.J. Nitrogen metabolism in higher plants. In Plant Amino Acids: Biochemistry and Biotechnology; Singh, B.K., Ed.; CRC Press: Boca Raton, FL, USA, 1999; p. 47.

32. Westgate, M.E.; Otegue, M.E.; Andrade, F.H. Physiology of the corn plant. In Corn: Origine, History, Technology and Production; Smith, C.W., Ed.; John Wiley \& Sons: Hoboken, NJ, USA, 2004; p. 935.

33. Leikam, D.; Randall, G.; Mallarino, A. A further look into fertilizer recommendation adequacy regarding phosphorus and potassium. Fluid J. 2010, 18, 8-11.

34. Bruun, S.; Luxhoi, J.; Magid, J.; Deneergaard, A.; Jensen, L. A nitrogen mineralization model based on relationships for gross mineralization and immobilization. Soil Biol. Biochem. 2006, 38, 2712-2721. [CrossRef]

35. Clément, A.; Ladha, J.K.; Chalifour, F.P. Crops residue effects on nitrogen mineralization, microbial biomass, and rice yield in submerged soils. Soil Sci. Soc. Am. J. 1995, 59, 1595-1603. [CrossRef]

36. Ransom, J.K.; Carsky, R.J.; Palmer, A.F.E. World Corn Production Practices: Corn, Origin, History, Technology, and Production; Wiley Series in Crop Science; Wiley: Hoboken, NJ, USA, 2004; p. 949.

37. Espinoza, L.; Ross, J. Fertilization and liming. In Corn Production Handbook; Espinoza, U.A., Ed.; University of Arkansas: Fayetteville, AR, USA, 2009; p. 97.

38. Shepard, A.; Thomison, P.; Nafziger, E.; Mullen, R.; Clucas, C. Nutridense corn response to nitrogen rates. Agron. J. 2011, 103, 169-174. [CrossRef]

39. Halvorson, D.A.; Schweissing, F.C.; Bartolo, M.E.; Reule, C.A. Corn response to nitrogen fertilization in a soil with high residual nitrogen. Agron. J. 2005, 97, 1222-1229. [CrossRef]

40. Gehl, R.J.; Schmidt, J.P.; Maddux, L.D.; Gordon, W.B. Corn yield response to nitrogen rate and timing in sandy irrigated soils. Agron. J. 2005, 97, 1230-1238. [CrossRef]

41. Heckman, J.R.; Hlubik, W.T.; Prostak, D.J.; Paterson, J.W. Pre-side dress soil nitrate test for sweet corn. Hortscience 1995, 30, 1033-1036.

42. Hartz, T.K. Vegetable production best management practices to minimize nutrient loss. Hort. Technol. 2006, 16, 398-403.

43. Guillard, K.; Morris, T.F.; Kopp, K.L. The Pre-side dress soil nitrate test and nitrate leaching from Corn. J. Environ. Qual. 1999, 28, 1845-1852. [CrossRef] 
44. Ma, L.B.; Subedi, K.D.; Costa, C. Pre-side dress nitrate test and other crop based indicators for fresh market and processing sweet corn. Agron. J. 2007, 99, 384-389. [CrossRef]

45. Hatfield, J.L.; Gitelson, A.A.; Schepers, J.S. Application of spectral remote sensing for agronomic decisions. Agron. J. 2008, 117-131. [CrossRef]

46. Pinter, P.J., Jr.; Hatfield, J.L.; Schepers, J.S.; Barnes, E.M.; Moran, M.S.; Daughtry, C.S.T.; Upchurch, D.R. Remote sensing for crop management. Photogramm. Eng. Remote Sens. 2003, 69, 647-664. [CrossRef]

47. Dwyer, L.M.; Tollenaar, M.; Muldon, J.F. A non-destructive method to monitor leaf greenness in corn. Can. J. Plant Sci. 1997, 71, 505-509. [CrossRef]

48. Markwel, J.; Osternman, J.C.; Mitchell, J.L. Calibration of the minolta SPAD-502 leaf chlorophyll meter. Photosynth. Res. 1995, 46, 467-472. [CrossRef] [PubMed]

49. Dey, A.K.; Sharma, M.; Meshram, M.R. An analysis of leaf chlorophyll measurement method using chlorophyll meter and image processing technique. Procedia Compt. Sci. 2016, 85, 286-292. [CrossRef]

50. Piekielek, W.P.; Fox, R.H. Use of chlorophyll meter to predict side dress nitrogen requirements for maize. Agron. J. 1992, 84, 59-65. [CrossRef]

51. Blackmer, T.M.; Schepers, J.S. Use of a chlorophyll meter to monitor nitrogen status and schedule FERTIGATION for Corn. J. Prod. Agric. 1995, 8, 56-60. [CrossRef]

52. Varvel, G.E.; Schepers, J.S.; Francis, D.D. Ability for In-season correction of nitrogen deficiency in corn using chlorophyll meters. Soil Sci. Soc. Am. J. 1997, 61, 1233-1239. [CrossRef]

53. Zhang, J.; Blackmer, A.M.; Ellsworth, J.W.; Koehler, K.J. Sensitivity of chlorophyll meters for diagnosing nitrogen deficiencies of corn in production agriculture. Agron. J. 2008, 100, 543-550. [CrossRef]

54. Cartelat, A.; Cerovic, Z.G.; Goulas, Y.; Meyer, S.; Lelarge, C.; Prioul, J.-L.; Barbottin, A.; Jeuffroy, M.-H.; Gate, P.; Agati, G.; et al. Optically assessed contents of leaf polyphenolics and chlorophyll as indicators of nitrogen deficiency in wheat (Triticum aestivum L.). Field Crop. Res. 2005, 91, 35-49. [CrossRef]

55. Sripada, P.R.; Heiniger, R.W.; White, J.G.; Meijer, D.A. Aerial color infrared photography for determining early-season nitrogen requirements in corn. Agron. J. 2006, 97, 1443-1451. [CrossRef]

56. Scharf, P.C.; Lory, J.A. Calibrating reflectance measurements to predict optimal side dress nitrogen rate for corn. Agron. J. 2002, 101, 615-625. [CrossRef]

57. Ma, B.L.; Morrison, M.J.; Dwyer, L.M. Canopy light reflectance and field greenness to assess nitrogen fertilization and yield of corn. Agron. J. 1996, 88, 915-920. [CrossRef]

58. Shanahan, J.F.; Schepers, J.S.; Francis, D.D.; Varvel, G.E.; Wilhelm, W.; Tringe, J.M.; Schlemmer, M.R.; Major, D.J. Use of remote-sensing imagery to estimate corn grain yield. Agron. J. 2001, 93, 583-589. [CrossRef]

59. Shanahan, J.F.; Holland, K.H.; Schepers, J.S.; Francis, D.D.; Schlemmer, M.R.; Caldwell, R. Use of a crop canopy reflectance sensor to assess corn leaf chlorophyll content. ASA Spec. Publ. 2003, 66, 135-150.

60. Raun, R.W.; Solie, J.B.; Johnson, G.V.; Stone, M.L.; Mullen, R.W.; Freeman, K.W.; Thomason, W.E.; Lukina, E.V. Improving nitrogen use efficiency in cereal grain production with optical sensing and variable rate application. Agron. J. 2002, 94, 815-820. [CrossRef]

61. Mullen, W.R.; Kyle, W.F.; Raun, W.R.; Johnson, G.V.; Stone, M.L.; Solie, J.B. Identifying an in-season response index and the potential to increase wheat yield with nitrogen. Agron. J. 2003, 95, 347-351. [CrossRef]

62. Goulas, Y.; Cerovic, A.; Cartelat, A.; Moya, I. Dualex: A new instrument for field measurements of epidermal ultraviolet absorbance by chlorophyll fluorescence. Appl. Opt. 2004, 43, 4488-4496. [CrossRef] [PubMed]

63. Varvel, G.E.; Wilhelm, W.W.; Shanahan, J.F.; Schepers, J.S. An algorithm for corn nitrogen recommendations using a chlorophyll meter based sufficiency index. Agron. J. 2007, 99, 701-706. [CrossRef]

64. Schelmmer, M.; Gitelson, A.; Schepers, J.; Ferguson, R.; Peng, Y.; Shanahan, J.; Rundquist, D. Remote estimation of nitrogen and chlorophyll contents in maize at leaf and canopy levels. Int. J. Appl. Earth Obs. Geoinform. 2013, 25, 47-54. [CrossRef]

65. Bhandari, A.K.; Kumar, A.; Singh, G.K. Feature extraction using normalized difference vegetation index (NDVI): A case study of Jabalpur city. Procedia Technol. 2012, 6, 612-621. [CrossRef]

66. Freeman, W.K.; Girma, K.; Arnall, D.B.; Mullen, R.W.; Martin, K.L.; Teal, R.K.; Raun, W.R. By-plant prediction of corn forage biomass and nitrogen uptake at various growth stages using remote sensing and plant height. Agron. J. 2007, 99, 530-536. [CrossRef] 
67. Barnes, E.M.; Clarke, T.R.; Richards, S.E.; Colaizzi, P.D.; Haberland, J.; Kostrzewski, M.; Waller, P.; Choi, C.; Riley, E.; Thompson, T.; et al. Coincident detection of crop water stress, nitrogen status and canopy density usingground-based multispectral data. In Proceedings of the Fifth International Conference of Precision Agriculture, Madison, WI, USA, 16-19 July 2000.

68. Fitzgerald, G.J. Characterizing vegetation indices derived from active and passive sensors. Int. J. Remote Sens. 2010, 31, 4335-4348. [CrossRef]

69. Martin, K.L.; Girma, K.; Freeman, K.W.; Raun, W.R. Expression of variability in corn as influenced by growth stage using optical sensor measurements. Agron. J. 2007, 99, 384-389. [CrossRef]

70. Karcher, E.D.; Richardson, M.D. Quantifying turf grass color using digital image analysis. Crop Sci. 2003, 43, 943-951. [CrossRef]

71. Rhezali, A.; Purcell, L.C.; Roberts, T.L. Evaluation of Dark Green Color Technology as a Method of Real Time in Season Maize Nitrogen Measurement and Evaluation. Master's Thesis, University of Arkansas, Fayetteville, AR, USA, 2016; p. 103.

72. Bai, H. High Throughput Phenotypic Evaluation of Drought-Related Traits in Soybean. Ph.D. Thesis, University of Arkansas, Fayetteville, AR, USA, 2016; p. 191.

(C) 2017 by the authors. Licensee MDPI, Basel, Switzerland. This article is an open access article distributed under the terms and conditions of the Creative Commons Attribution (CC BY) license (http:/ / creativecommons.org/licenses/by/4.0/). 